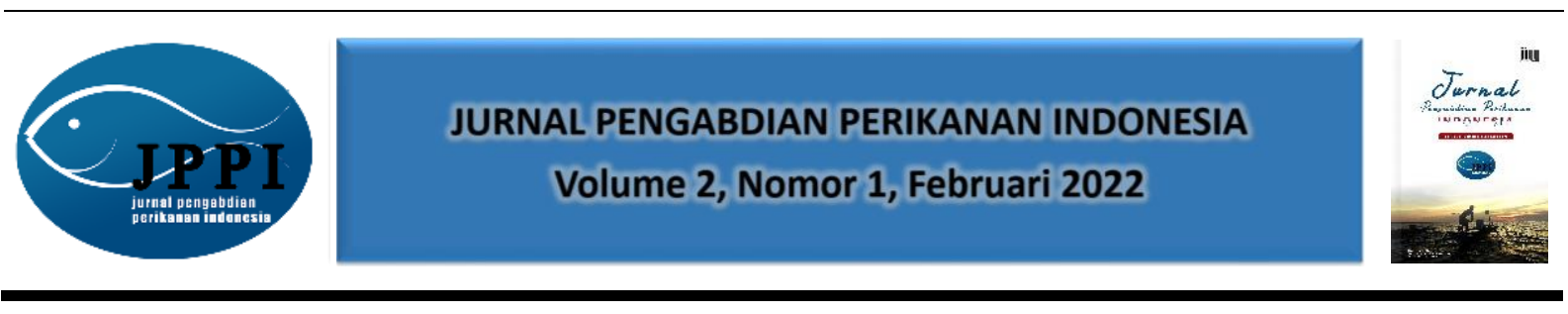

\title{
PENGOLAHAN COKELAT BATANGAN DENGAN PENAMBAHAN TEPUNG RUMPUT LAUT SEBAGAI PENGGANTI LESITIN
}

\author{
Tamrin*1 $^{* 1}$, Nur Asyik ${ }^{1}$, Sri Rejeki ${ }^{1}$, F. Faradillah ${ }^{1}$, A. Madiki ${ }^{2}$, La Karimuna ${ }^{2}$, La Ode Nafiu ${ }^{3}$, T. Saili ${ }^{3}$, \\ La Aba ${ }^{4}$, Sarmin ${ }^{1}$ \\ ${ }^{1} J u r u s a n$ IImu dan Teknologi Pangan Universitas Halu Oleo, ${ }^{2} J u r u s a n$ Agroteknologi Universitas \\ Halu Oleo, ${ }^{3}$ Jurusan Produksi Ternak Universitas Halu Oleo, ${ }^{4}$ Jurusan Fisika Univesitas Halu Oleo
}

Gedung Jurusan ITP-FP Lt. 1 Kampus Hijau Bumi Tridharma Anduonohu Kendari Sulawesi

Tenggara Indonesia, 93232

*Alamat korespondensi : tamrinkendari@yahoo.co.id

Keyword: Abstrak:

Kakao, Cokelat batangan adalah salah satu produk olahan sekunder dari biji kakao kering. cokelat, Cokelat batangan banyak digemari oleh berbagai kalangan masyarakat, namun rumput proses pengolahannya belum banyak diketahui sehingga praktek penjualan langsung laut, biji kakao kering masih lazim di masyarakat, walaupun diketahui UU nomor 13 tahun pengemulsi 2014 tentang perindustrian telah mengamanahkan proses percepatan hilirisasi produk. Proses pengolahan cokelat batangan umumnya menggunakan pengemulsi lesitin soya yang harus dibeli dari luar Sulawesi Tenggara. Sementara beberapa kabupaten di Sulawesi Tenggara dikenal sebagai wilayah penghasil rumput laut yang dalam bentuk tepung dapat digunakan sebagai pengganti lesitin. Oleh karena itu dilakukan kegiatan pengabdian masyarakat berupa sosialisasi dan pelatihan pengolahan cokelat batangan menggunakan tepung rumput laut sebagai pengganti lesitin soya. Kegiatan ini dilaksanakan di Pusat Pengembangan Kompotensi Industri Pengolahan Kakao Terpadu LPPM Universitas Halu Oleo Kendari. Metode kegiatan dilaksanakan dalam bentuk sosialisasi dan penyampaian materi, diskusi dan praktek pengolahan cokelat batangan dari biji kakao kering dengan penambahan tepung rumput laut. Peserta terdiri dari pelaku industri kecil pengolahan kakao Desa Malaha Kabupaten Kolaka dan Desa Ngapa (Kabupatan Kolaka Utara) serta beberapa anggota Lembaga Ekonomi Masyarakat Sejahtera dari beberapa desa di kabupaten Kolaka dan Kolaka Utara. Diakhir kegiatan dihasilkan produk cokelat batangan yang dikemas dan diberi label Sultan Cokelat (yang merupakan akronim dari Sulawesi Tenggara Negeri Cokelat. Peserta dapat mengerti dan memahami proses pengolahan cokelat batangan yang terlihat dari produk yang dihasilkan pada saat kegiatan praktek, sehingga diharapkan kegiatan ini dapat dilanjutkan dan diduplikasi ditempatnya masing-masing terutama oleh pelaku industri dari Desa Malaha dan Desa Ngapa

Panduan Sitasi (APPA $7^{\text {th }}$ edition) : 
Tamrin., Asyik, N., Rejeki, S., Faradillah, F., Madiki, A., Karimuna, L., Nafiu, L. O., Saili, T., Aba, L., \& Sarmin. (2022). Pengolahan Cokelat Batangan Dengan Penambahan Tepung Rumput Laut Sebagai Pengganti Lesitin. Jurnal Pengabdian Perikanan Indonesia, 2(1), 35-44. https://doi.org/10.29303/jppi.v2i1.516.

\section{PENDAHULUAN}

Penjualan langsung biji kakao kering masih menjadi kegiatan yang lazim terjadi di masyarakat, walaupun diketahui UU nomor 13 tahun 2014 tentang perindustrian telah mengamanahkan proses percepatan hilirisasi produk. Disamping itu, penjualan biji kakao kering memberikan nilai tambah yang rendah. Untuk itu dipandang penting melakukan kegiatan pengabdian kepada masyarakat berupa pengolahan sekunder biji kakao. Kegiatan ini merupakan upaya penting bagi peningkatan nilai tambah komoditi yang diharapkan berdampak pada peningkatan status ekonomi dan kemandirian petani kakao.

Biji kakao yang dapat di gunakan sebagai bahan baku dalam pembuatan minuman, campuran gula-gula dan berbagai jenis makanan lain serta bahan kosmetik dan obat-obatan. Sebagai bahan baku industri pangan, komoditi kakao yang digunakan, menuntut mutu biji kakao yang betul- betul baik (khususnya sebagai bahan baku pada pembuatan berbagai produk coklat yang bermutu tinggi). Dengan demikian tidak hanya sekedar jumlah yang harus diusahakan tetapi juga mutu atau kualitas biji kakao

Kakao adalah komoditi perkebunan yang cukup banyak menyerap tenaga kerja, baik ditingkat budidaya sampai proses hilirisasi. Indonesia termasuk pengahasil kakao terbesar ketiga didunia (dan terbanyak di kawasan Sulawesi). Data menunjukkan bahwa propinsi Sulawesi Tenggara memiliki luas areal tanaman kakao sebesar 250,338 Ha dan produksi 148,746 ton (Disbunhorti Sultra, 2013).

Hasil produksi kakao Sulawesi Tenggara sebagian besar diekspor dalam bentuk bahan mentah berupa biji kakao kering yang umumnya tidak difermentasi. Hal ini cukup memprihatinkan karena harga biji kakao kering Indonesia di pasaran internasional lebih rendah dibandingkan harga rata-rata kakao dunia dan kadang dikenakan potongan harga (Goenadi et al., 2005; Supriyanto et al., 2007). Untuk itu diperlukan perbaikan penanganan pasca panen dan pengolahan sekunder biji kakao khususnya pengolahan cokelat batangan.

Pengolahan cokelat batangan lazimnya menggunakan lesitin soya sebagai pengemulsi. Namun lesitin soya merupakan bahan pengemulsi yang didatangkan dari luar Sulawesi Tenggara. Disisi lain, beberapa daerah di Sulawesi Tenggara dikenal sebagai penghasil rumput laut yang dapat diolah menjadi tepung. Beberapa hasil percobaan menunjukkan bahwa tepung rumput laut dapat digunakan sebagai pengganti lesitin dalam proses pengolahan cokelat batangan. Penggunaan tepung rumput laut sebagai pengganti lesitin belum banyak digunakan dalam industri pengolahan cokelat. Oleh karena itu penerapannya dalam proses pengolahan cokelat khusunya di industri skala kecil sangat perlu disosialisasikan dan dipraktekkan sehingga pemanfaatan sumber daya alam lokal dapat meningkat.

\section{METODE KEGIATAN}

Kegiatan pengabdian dilaksanakan selama tiga hari. Tempat pelaksanaan kegiatan berlangsung di Industri Pengolahan Kakao - Pusat Pengembangan Kompetensi Industri Pengolahan Kakao Terpadu LPPM Universitas Halu Oleo Kendari.

Metode pengabdian dilaksanakan dengan cara sosialisasi dan praktek pengolahan cokelat batangan dengan penambahan tepung rumput laut sebagai pengganti lesitin. Peserta terdiri dari pelaku industri kecil pengolahan cokelat desa Malaha Kabupaten Kolaka dan desa Ngapa (Kabupatan 
Kolaka Utara) serta beberapa anggota Lembaga Ekonomi Masyarakat Sejahtera dari beberapa desa di kabupaten Kolaka dan Kolaka Utara, sehingga Jumlah peserta seluruhnya adalah 31 orang.

Kegiatan pengabdian diawali dengan penyampaian materi gambaran umum pengolahan sekunder biji kakao, yang dilanjutkan dengan praktek pembuatan pasta kakao dan cokelat batangan denga penambahan tepung rumput laut. Adapun tahapan prosesnya meliputi proses penyangraian biji kakao kering, pengupasan biji kakao menggunakan alat Nib Shell Separator, Penyangraian nib kakao, penggilingan nib kakao menggunakan stone mill dan ballmill untuk menghasilkan Pasta kakao. Pasta kakao selanjutnya diolah menjadi cokelat batagan yang diawali dengan proses pencampuran bahan yang terdiri dari Pasta Kakao, Susu bubuk, gula, lemak kakao, tepung rumput laut dan vanili. Tahap berikutnya adalah penghalusan adonan menggunakan ballmill, proses tempering, pencetakan. Cokelat yang telah dicetak dimasukkan dalam mesin pendingin sehingga cokelatnya mengeras. Selanjutnya dilakukan pengemasan dan labeling.

\section{HASIL DAN PEMBAHASAN}

Kegiatan pengabdian diawali dengan sosialisasi manfaat mengkonsumsi cokelat, pengenalan jenis-jenis cokelat yang ada dipasaran dan proses pengolahan biji kakao kering sampai menjadi cokelat batangan. Kegiatan sosialisasi ini dihadirioleh peserta yang terdiri dari pelaku industri cokelat dari desa Malaha Kabupaten Kolaka dan desa Ngapa Kabupaten Kolaka Utara serta beberapa petani yang menjadi anggota Lembaga Ekonomi Masyarakat Sejahtera.

Berdasarkan hasil diskusi selama kegiatan diketahui bahwa sebagian besar peserta pelatihan belum mengenal jenis-jenis cokelat yang ada dipasaran. Kepada peserta dikenalkan dua jenis cokelat yaitu couverture dan compound. Cokelat couverture yaitu cokelat yang dibuat dengan bahan utama terdiri dari pasta dan lemak kakao (cocoa butter) yang ditambahkan gula dan susu serta beberapa bahan tambahan pangan lainnya. Adapun cokelat compound, adalah cokelat yang dibuat dengan bahan utaram terdiri dari pasta kakao dan lemak CBS (cocoa butter substitusi). CBS adalah lemak yang dikembangkan dari minyak sawit melalui proses hidrogenasi. Adapun bahan tambahan lain dari cokelat compound sama dengan cokelat couverture. Kedua jenis cokelat tersebut memiliki varian rasa yang umumnya terdiri dari milk cokelat dan dark cokelat. Bagi penggemar cokelat umummnya lebih meminati cokelat couverture terutama dark cokelat.

Kegiatan ini sangat diharapkan dapat memberikan tambahan pengetahuan dan informasi untuk peserta sehingga dapat membuat sendiri cokelat batangan dari biji kakao kering. Pengetahuan dan keterampilan tersebut dapat menajdi pemicu untuk menggagas upaya terbangunnya kerjasama antara petani kakao dan pelaku usaha industri pengolahan cokelat. Kerjasama tersebut diharapkan telah dapat dikomunikasikan dan diinisiasi selama kegiatan pengabdian berlangsung sehingga dapat dibangun kesepahaman untuk distribusi nilah tambah yang berkeadilan bagi semua pelaku usaha baik hulu maupun hilir. Karena kondisi faktual menunjukkan bahwa produk olahan kakao berupa cokelat ataupun produk lainnya memiliki nilai tambah yang sangat tinggi. Namun nilai tambah tersebut kadang hanya dirasakan oleh pelaku usaha industri pengolahan ditingkat hilirisasi, dan sangat sedikit dinikmati oleh petani. Bagi kebanyakan penggemar cokelat mengetahui bahwa harga produk cokelat batangan tidak pernah turun bahkan kadang naik ditahun-tahun berikutnya, sementara harga biji kakao kering terjadi fluktuasi. Oleh karena itu saling kenal dan keakraban selama kegiatan pengabdian terus dipupuk dan diharapkan terus berlanjut. Demikianlah harapanharapan yang disampaikan selama proses sosialisasi dan praktek. Peserta sosialisasi pengolahan cokelat batangan dengan penambahana tepung rumput laut dapat dilihat pada Gambar 1. 


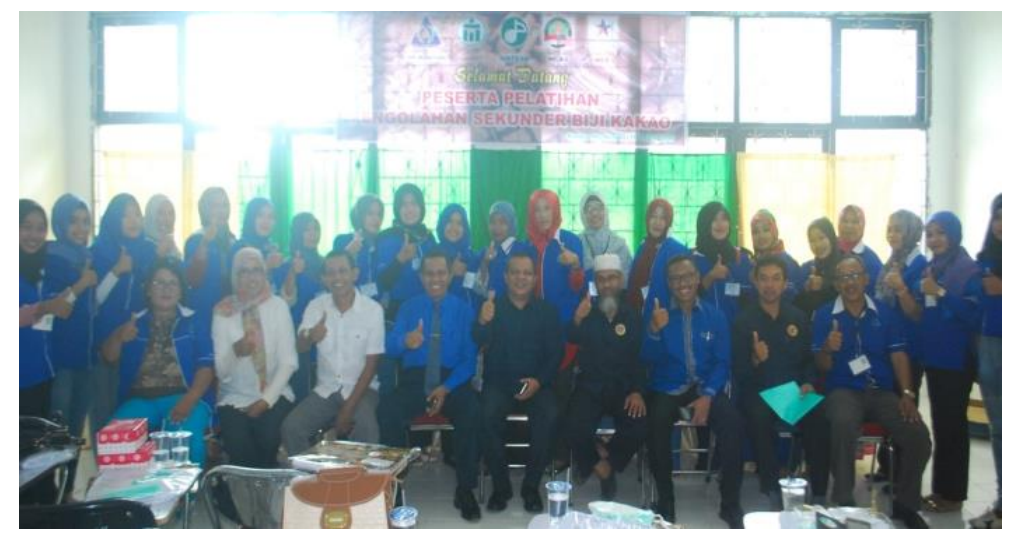

Gambar 1. Peserta sosialisasi pengolahan cokelat batangan

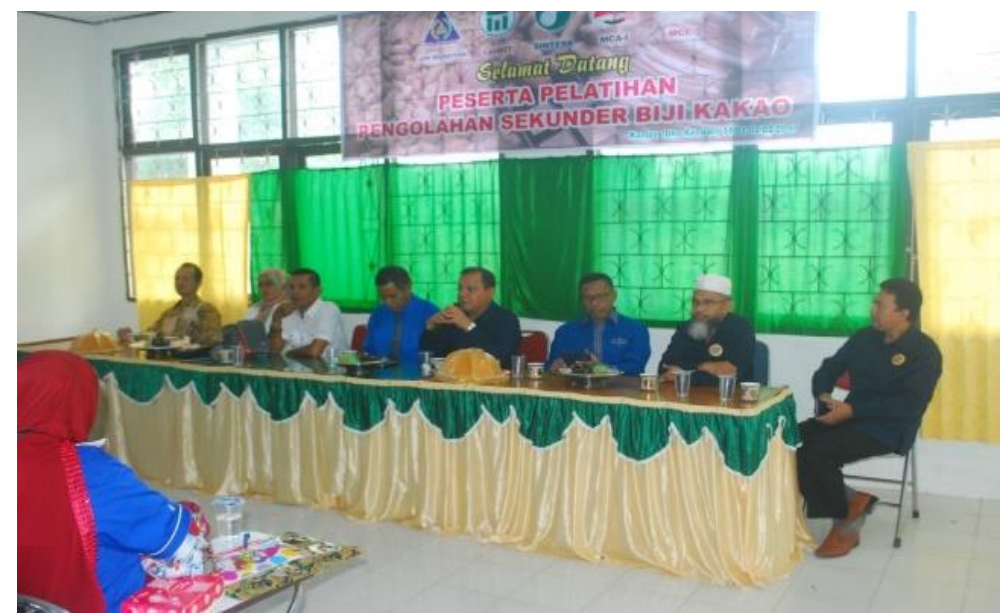

Gambar 2. Narasumber / instruktur saat menyampaikan materi sosialisasi pengolahan cokelat batangan

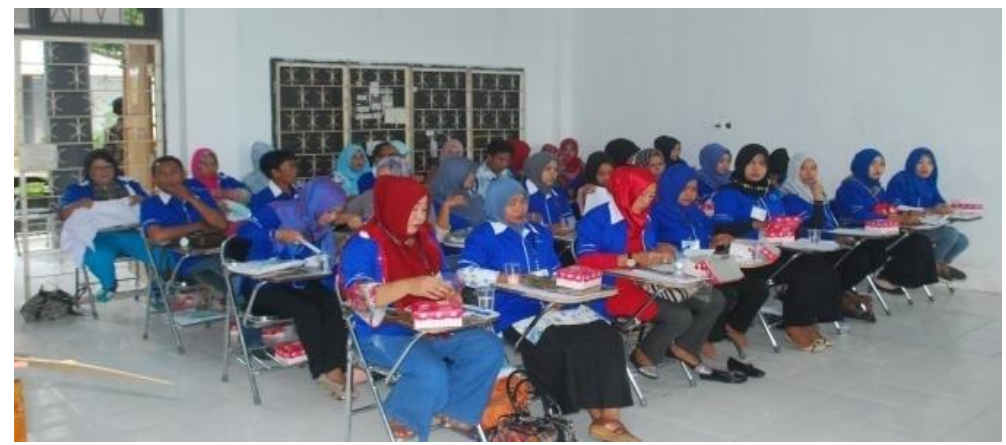

Gambar 3. Peserta saat mengikuti sosialisasi penyampaian materi sosialisasi pengolahan cokelat batangan

Peserta pelatihan terlihat sangat antusias selama kegiatan berlangsung. Hal ini antara lain karena selama ini peserta belum pernah melakukan proses pengolahan cokelat batangan langsung dari biji kakao kering yang dihasilkan dari wilayah mereka. Beberapa peserta menjelaskan bahwa mereka pernah membuat cokelat batangan tapi dari cokelat block yang dobeli dipasar, dilelehkan dan dicetak kembali dalam ukuran yang lebih kecil.

Kemampuan peserta dalam memahami materi-materi yang diberikan selama kegiatan pengabdian dapat dievaluasi dari berbagai aspek antara lain :

\section{A. Aspek manfaat kakao dan cokelat bagi kesehatan}


Narasumber / instruktur telah memaparkan tentang manfaat mengkonsumsi kakao bagi kesehatan pada saat kegiatan pengabdian. Beberapa efek kesehatan dari menkonsumsi kakao juga menjadi bahan pertimbangan penting, termasuk fungsi jantung membaik dan relief angina pektoris, rangsangan sistem saraf, memfasilitasi pencernaan, dan ginjal serta meningkatkan fungsi usus. Selain itu, kakao telah digunakan untuk mengobati anemia, kelelahan mental, TBC, demam, encok, batu ginjal, dan bahkan turunnya nafsu seksual (Corti et al., 2009). Dalam studi in vitro dengan sel mononuklear darah perifer menunjukkan bahwa fraksi murni procyanidin cocoa, serta ekstrak kasar cokelat, dapat mengubah transkripsi sitokin, menunjukkan bahwa produk-produk alami memiliki potensi untuk memodulasi respon imun (Kenny et al., 2004). Mekanistik pengamatan ini dapat memberikan dasar untuk tubuh besar literatur epidemiologi yang menunjukkan bahwa konsumsi rutin makanan kaya flavonoid, seperti yang ditemukan dalam teh dan cocoas tertentu dan coklat, terkait dengan penurunan risiko penyakit jantung koroner, stroke, dan kanker tertentu (Kenny et al., 2004; Rawel dan Kulling, 2007).

Dijelaskan juga kepada peserta bahwa salah satu keunggulan cokelat batangan yang dihasilkan dari kegiatan ini mempunyai antioksidan yang cukup tinggi karena yang diolah dari biji kakao asal dari Sulawesi Tenggara. Berdasarkan hasil penelitian biji kakao Sulawesi Tenggara memiliki antioksidan yang tinggi (Tamrin et al., 2012). Hasil penelitian lainnya juga menjelaskan bahwa biji kakao Sulawesi memiliki antioksidan lebih tinggi dibandingkan dengan biji kakao Malaysia, Ghana dan Pantai Gading (Othman et al., 2010).

Selama penyampaian materi peserta diberikan kesempatan untuk bertanya. Terlihat begitu tinggi minta peserta untuk mengetahui manfaat konsumsi kakao/coeklat terutama kaitannya dengan kesehatan tubuh.

\section{B. Aspek produk saos tomat}

Produk Cokelat batangan yangdihasilkan dalam kegiatan pengabdian ini berupa cokelat batangan dengan penambahan rumput laut sebagai sumberdaya lokal sehingga semakin menguatkan produk ini dengan sumber daya lokal. Ukuran produk yaitu panjang $10.5 \mathrm{~cm}$, lebar $2.5 \mathrm{~cm}$ dan tebal $1.2 \mathrm{~cm}$ dengan berat bersih $35 \mathrm{gram} /$ bungkus. Produk ini dikemas menggunakan aluminium sebagai kemasan primer dan kemasan kertas yang dilengkapi merk/label Sultan Cokelat (merupakan akronim dari Sulawesi Tenggara Negeri Cokelat).

Merk Sultan Cokelat yang ditampilkan dalam kegiatan pengabdian hanya sebagai contoh bagi peserta sehingga dapat diperoleh gambaran nilai tambah yang cukup tinggi jika biji kakao dapat diolah menjadi cokelat batangan.

Sebagai perbandingan, produk Sultan Cokelat tersebut secara komersil dapat terjual dalam kisaran harga $\mathrm{Rp} 8.000$,- sampai Rp 10.000,-. Sementara produk yang sejenis dengan kualitas dan ukuran yang sama dijumpai dipasaran dengan harga yang lebih tinggi. Dengan demikian diharapkan peserta dapat tertarik dan bersemangat mengembangkan produk cokelat batangan untuk menambah penghasilan keluarga.

\section{Aspek pengolahan cokelat batangan}

Kegiatan pertama dalam proses pengolahan cokelat batangan adalah penyampaian tata tertib selama diruang produksi dan pengenalan alat/mesin pengolahan cokelat batangan. Kepada peserta diingatkan pentingnya memperhatikan SSOP (Sanitation Standard Operating Procedures) dan GMP (Good Manufacturing Practices) selama proses pengolahan cokelat batangan. 


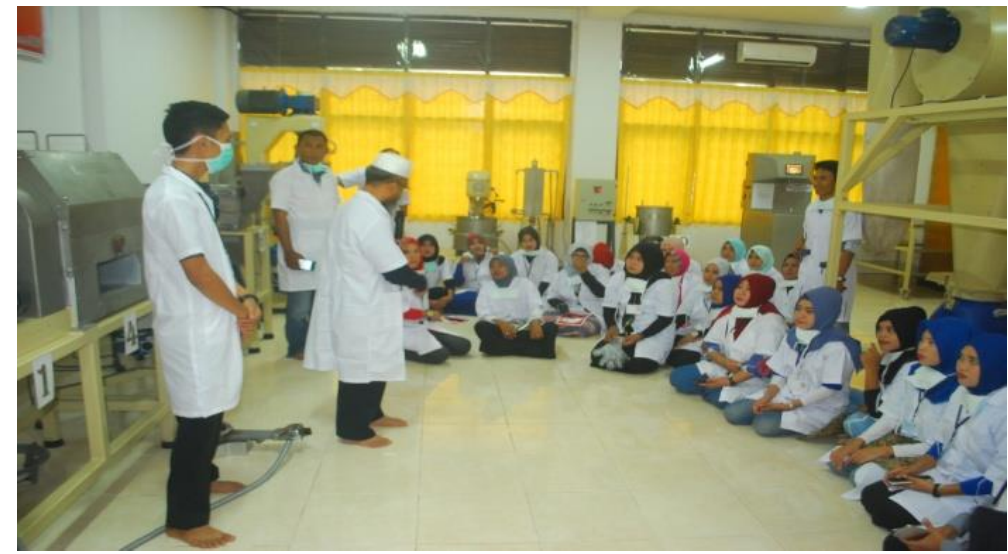

Gambar 4. Penyampaian materi pengenalan alat dan SSOP serta GMP.

Pengolahan diawali dengan penyiapan biji kakao kering. Kepada peserta dijelaskan ciri biji kakao yang siap disangrai yang jika diukur kadar airnya berkisar antara 6-7\%. Selain itu disampaikan juga bahan-bahan lainnya yang terdiri dari lemak kakao, gula, susu bubuk, tepung rumput laut dan vanili. Bahan-bahan tersebut daoat dilihat pada Gambar 5.
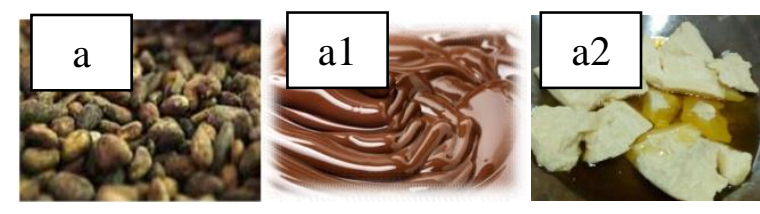

Gambar 5. Bahan utama yang digunakan untuk Pengolahan cokelat batangan (a) Biji kakao kering yang diolah menjadi pasta kakao (a1) dan Lemak kakao (a2).

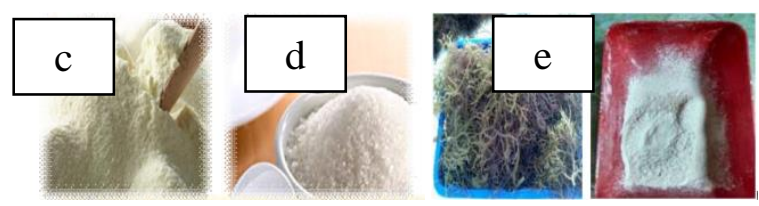

Gambar 6. Bahan tambahan pembuatan cokelat batangan : susu bubuk (c), gula (d), dan tepung rumput laut (e)

Tahapan pertama penglahan cokelat batangan yang disampaikan kepada peserta adalah proses pengolahan biji kakao menjadi pasta yang tahpannya meliputi penyangraian biji menggunakan mesin Roaster, pemisahan kulit dan nib kakao (biji kakao tanpa kulit) menggunakan mesin Nib Shell Separator, dan proses penyangraian dan penggilingan nib sampai menjadi pasta kasar (menggunakan mesin stone mill) serta pembuatan pasta halus menggunakan mesin balmill. Tahapan proses dapat dlihat pada Gambar 7.

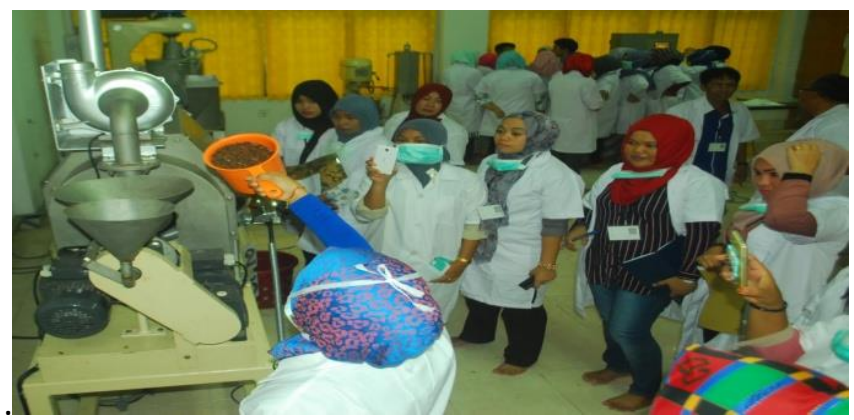

Gambar 7. Proses penyangraian biji kakao 


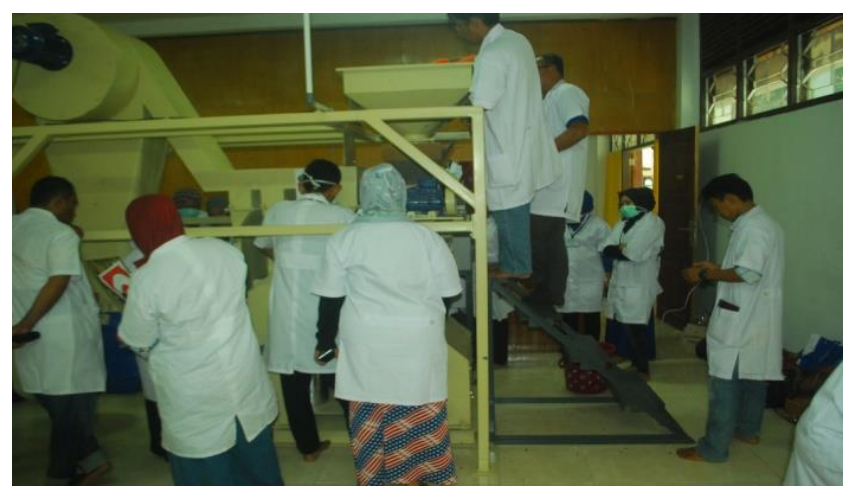

Gambar 8. Proses pemisahan kulit dan nib kakao

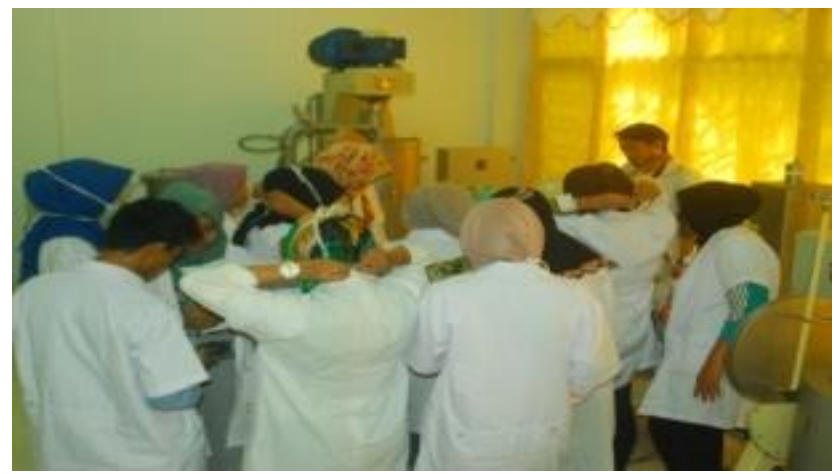

Gambar 9. Proses pembuatan pasta kakao

Gambar 7-8 menunjukkan proses pengolahan pengolahan biji kakao kering menjadi pasta kakao. Selanjutnya pasta kakao ditambahkan lemak kakao, susu bubuk, dan gula kemudian dicampur merata menggunakan mixer (Gambar 9).

Tahapan berikutnya adalah proses penghalusan adonan menggunakan ballmill selama $3-4$ jam. Dalam proses penghalusan ini ditambahkan tepung rumput laut sebagai pengganti lesitin. Kepada peserta dijelaskan bahwa penggunaan tepung rumput laut lebih menguntungkan dibanding menggunakan bahan pengemulsi lain. Hal ini antara lain karena rumput laut dapat diproduksi sendiri sedangkan bahan pengemulsi harus didatangkan dari luar Sulawesi Tenggara, bahkan kadang sulit diperoleh. Sementara tepung rumput dapat dengan mudah dihasilkan dengan cara menggiling rumput laut sampai diperoleh tingkat kehalusan 80 mesh.

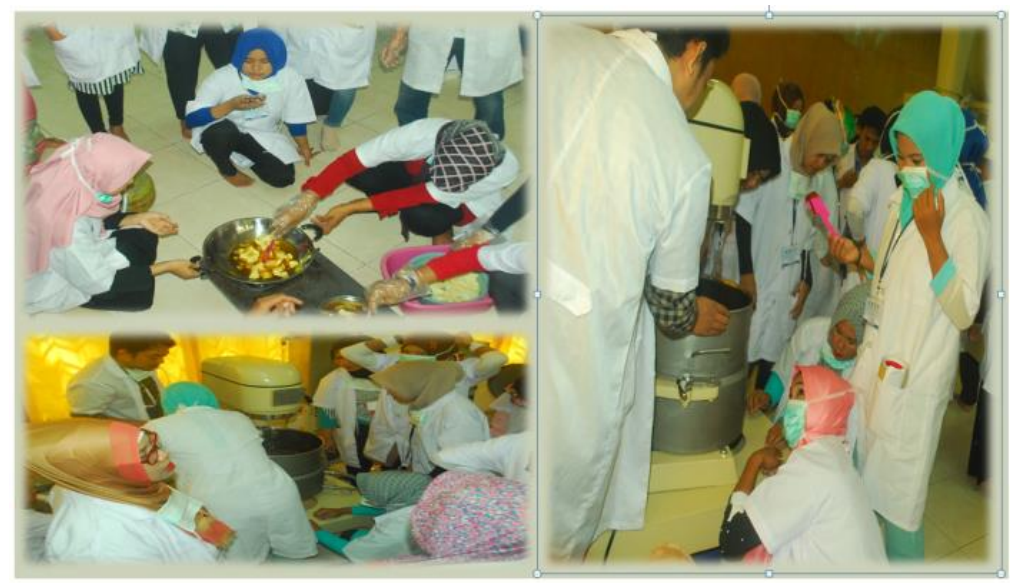

Gambar 10. Proses pembuatan adonan cokelat batanagan 


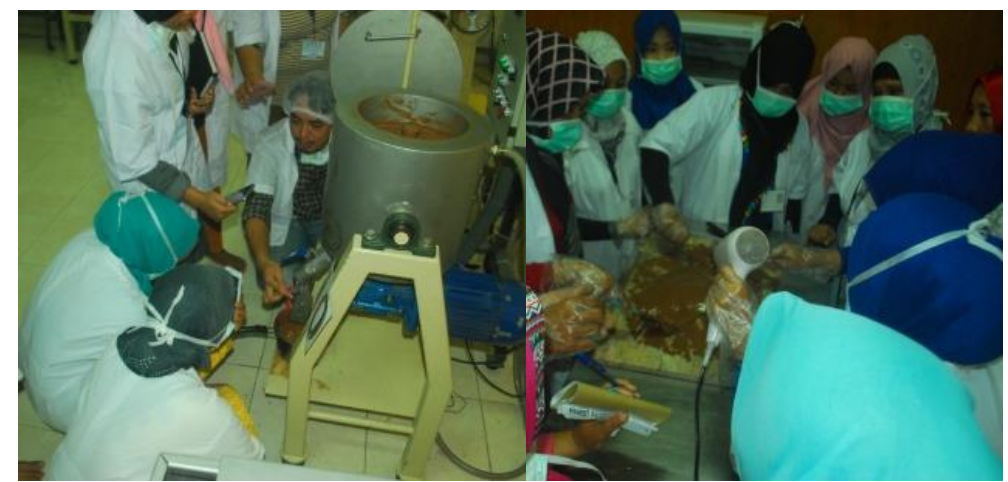

Gambar 11. Proses penghalusan adonan cokelat dan proses tempering

Kegiatan pengabdian juga dilakukan sampai proses penegmasan produk dan labeling. Praktek pengemasan produk dilakukan untuk meningkatkan pemahaman peserta terhadap pentingnya pengemasan produk pangan khususnya produk coklat batangan. Peserta diharapkan mampu mengetahui fungsi-fungsi kemasan suatu produk yang antara lain melindungi produk, meningkatkan nilai estetika, dan memberikan informasi dari produk berupa bahan baku dan bahan pendukung, tempat produksi, tanggal kedaluarsa, izin depkes (Dinkes P-IRT), SNI dll. Selain itu peserta juga diperkenalkan beberapa bahan dan alat kemasan serta praktek langsung cara pengemasan coklat batangan.

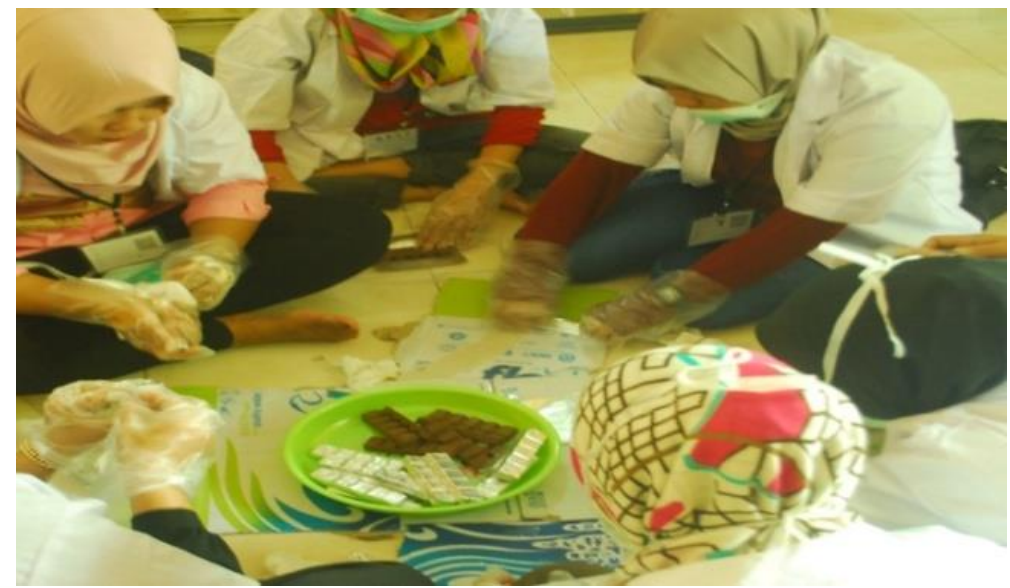

Gambar 12. Proses pengemasan produk cokelat batangan

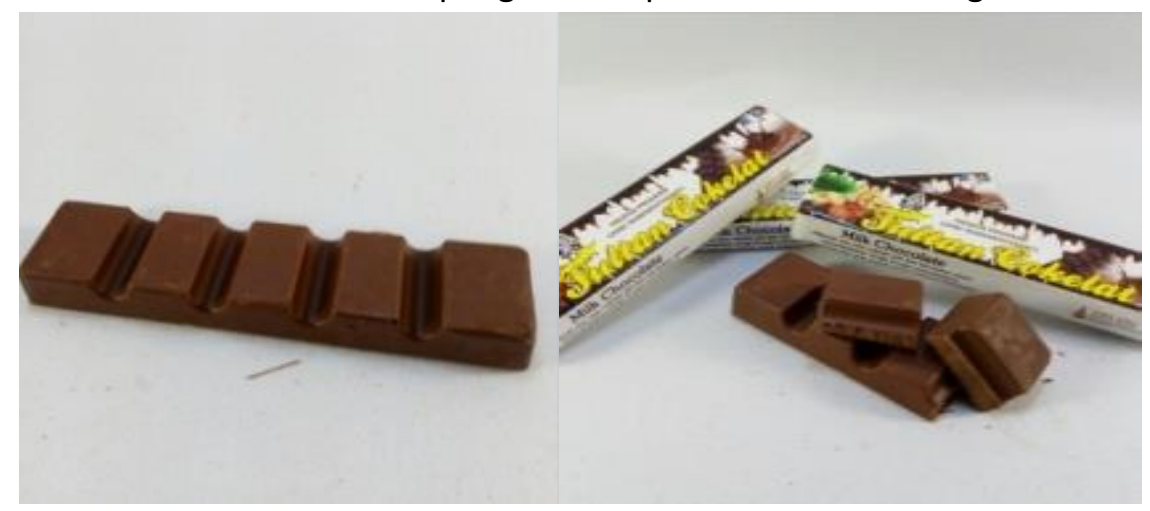

Gambar 13. Produk cokelat batangan yang dihasilkan dari kegiatan pengabdian masyarakat

Keunggulan cokelat batangan yang dihasilkan, selain mengandung antioksidan yang tinggi 
penambahan rumput laut sebagai pengganti lesitin juga meningkatkan jumlah serat pangan dalam cokelat batangan sehingga nilai fungsionalnya. Disamping itu, cokelat batangan yang dilatihkan pada peserta tidak menggunakan bahan pengawet sintetis.

Beberapa diskusi yang berlangsung selama kegiatan dapat diketahui keinginan peserta yang cukup tinggi untuk mempraktekkan proses pembuatan cokelat batangan diindustrinya khususnya untuk peserta dari Desa Malaha Kabupten Kolaka dan Desa Ngapa Kabupaten Kolaka Utara, yang memiliki peralatan industri pengolahan kakao skala kecil.

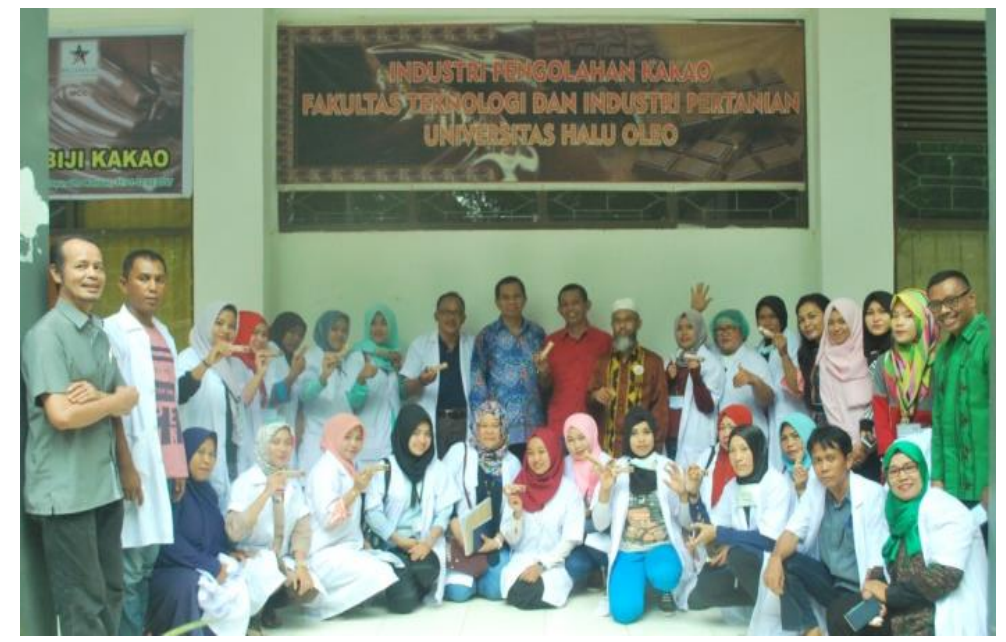

Gambar 14. Pseluruh peserta kegiatan bersama seluruh peserta pelatihan cokelat batangan.

\section{KESIMPULAN DAN SARAN}

Dari pengabdian ini dapat diambil kesimpulan sebagai berikut:

1. Peserta pengabdian masyarakat sangat serius dan bersemangat mengikuti kegiatan yang terlihat dari aktivitas dalam proses diskusi maupun selama praktek berlangsung..

2. Seluruh peserta mengikuti kegiatan sejak awal sampai akhir tanpa berkurang satu orang pun yang menunjukkan kesabaran dan ketekunan.

3. Peserta dapat mengerti dan memahami proses pengolahan cokelat batangan yang terlihat dari produk yang dihasilkan pada saat kegiatan praktek, sehingga diharapkan kegiatan ini dapat diduplikasi ditempatnya masing-masing terutama pelaku industri dari Desa Malaha dan Desa Ngapa.

\section{UCAPAN TERIMA KASIH}

Ucapan terima kasih kami sampaikan kepada: Rektor Universitas Halu Oleo, Ketua LPPM Universitas Halu Oleo, Kepala Pusat Pengembangan Kompotensi Industri Pengolahan Kakao Terpadu LPPM Universitas Halu Oleo, Konsorsium COCOA (Yayasan Bina Potensi Desa, Yayasan Sanmit dan LEM'S Kabupaten Kolaka dan Kolaka Utara) yang telah mendanai dan memfasilitasi kegiatan ini melalui dana program Millennium Challenge Account - Indonesia (MCA-Indonesia), Ketua Kelompok Industri Pengolahan Kakao di Desa Malaha Kabupaten Kolaka dan Desa Ngapa Kabupaten Kolaka Utara, dan Semua pihak yang tidak dapat disebutkan satu persatu.

\section{DAFTAR PUSTAKA}


Afoakwa E.O., 2008. Cocoa and ChoclateConsuption (Are thereaphrodisiac and otherbenefitfor human health?). S.Afr. J. Clin Nutr. : 21 (3): pp.107-112.

Belitz H.D., and W. Grosch, 1987. FoodChemistry. Translationfromthesecond German Editionby D. Hadziyev. Springer-VerlagBerlin. Heidelberg, Germany. p.703-711

Corti, R., A. J. Flammer, N. K. Hollenberg, T. F. Lüscher, 2009. Cocoa and Cardiovascular Health. Contemporary Reviews in Cardiovascular Medicine. American Heart Association, Inc. AHA Journal Circulation 119: pp. 1433-1441

Goenadi D.H., J.B.Baon., Herman, A. Purwoto. 2005. Prospek dan Arah Pengembangan Agribisnis Kakao di Indonesia. Balitbangtan-Deptan. Bogor.

Hannum S.M., and J.W. Erdman, 2004. Emerging Health Benefit from Cocoa and Chocolate. Journal of Medicine Food, Vol. 3(2): pp.73-75

Misnawi and W. Teguh, 2008. Potentials Uses of Cocoa Bean Infested by Conopomorpha cramerella for Polyphenol Extraction. ASEAN Food Journal 15 (12): pp. 27-34

Miller, K. B., Hurst, W. J., Payne, M. J., Stuart, D. A., Apgar, J., Sweigart, D. S., Ou, B. 2008. Impact of alkalization on the antioxidant and flavanol content of commercial cocoa powders., J. Agric. Food and Chem. 8527-8533.

Rawel H.M., andS.E.Kulling, 2007. Nutritional contributionofcoffee, cacao and teaphenolics to humanhealth. JournalofConsumer Protection and FoodSafety. J.Verbr.Lebensm. Germany, Vol.2: pp.399-406.

Tamrin, Harijono, Yuwono SS, Estiasih T, Santoso U. The change of catechin antioxidant during vacuum roasting of cocoa powder. J. Nutrition andFood Sci., 2012; 2 (10) :1-5. 